\title{
Possible primary sources of diamonds in Algeria
}

\author{
M. Kahoui ${ }^{1}$, Y. Mahdjoub ${ }^{1}$, M. Chabane ${ }^{2}$, F.V. Kaminsky ${ }^{3}$ \\ ${ }^{1}$ FSTGAT-USTHB, BP 32, Algiers, 16111, Algeria \\ ${ }^{2}$ ORGM, Direction régionale Sud, Tamanrasset, Algeria \\ ${ }^{3}$ KM Diamond Exploration Ltd, West Vancouver, Canada
}

In the 1980-90s, a sub-economic Djebel Aberraz diamond placer deposit was discovered in the Bled-elMas valley, approximately $30 \mathrm{~km}$ south of Reggane town (Fig. 1). Along with diamonds, numerous kimberlite indicator mineral (KIM) grains, such as pyrope garnet, chrome spinel and picroilmenite were identified in the deposit. These minerals are not related to any known primary source (Kaminsky et al., 1992a)

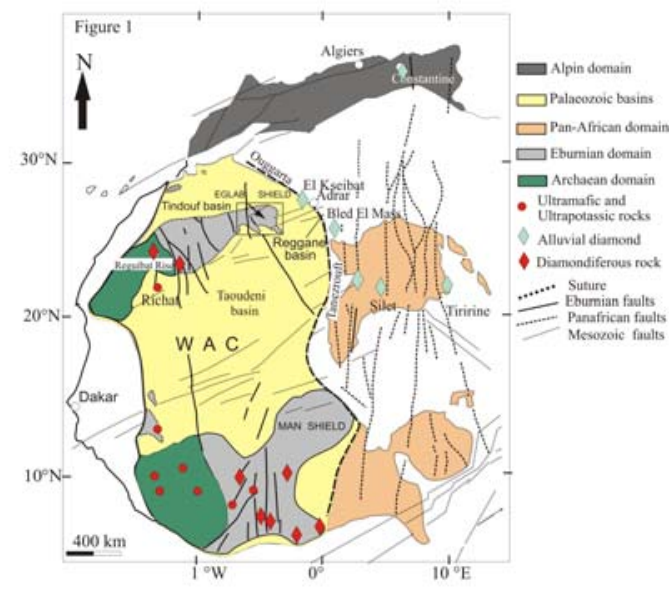

Fig. 1. Tectonic map of Northwestern Africa. The framed area is shown in detail in Fig. 4.

Besides the Djebel Aberraz, diamonds were found north and south of Reggane within a large area extending almost $300 \mathrm{~km}$ from Tanezrouft in the south to El Kseibat in the north, with the Djebel Aberraz placer deposit in the central part of this area (Fig. 1).

In 2000-2001, as the result of the work organized by the ORGM (Office National de la Recherche Géologique et Minière), pyrope garnet, picroilmenite and chromediopside dispersion halos were identified west of the Reggane area, within the 'Yetti-Eglab Junction' of the Eglab Shield which is the easternmost part of the Precambrian Reguibat Rise (West African Craton, WAC) (Labdi and Zénia 2001). The authors suggested a possibility of locating the primary sources of the diamonds within the Eglab Shield (Kahoui et al, 2008).

\section{Diamondiferous Djebel Aberraz area}

The Djebel Aberraz diamond placer deposit is located near the border of the Sahara Plate and the West African Craton. In the deposit, under a few meters of eolian sand, Lower-Upper Quaternary alluvial deposits
12-15 m thick overlay Palaeozoic sedimentary rocks (Fig. 2). In these alluvial sediments, about 1,500 diamond grains were recovered from exploration pits.

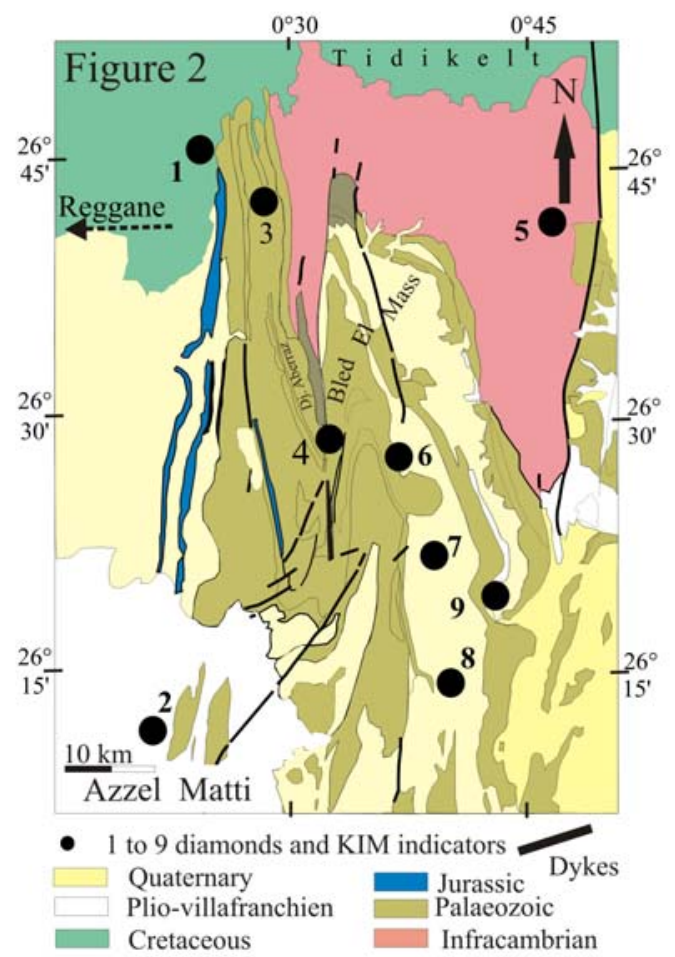

Fig. 2. Geological map of the Djebel Aberraz area.

Diamonds are mainly dodecahedral and transitional crystal forms, and more rarely ( $35 \%$ ) octahedra; the crystals bear evidence of mechanical erosion in ancient coastal-marine and recent fluvial environments. Some crystals contain inclusions represented by silicates, sulphides, and graphite. FTIR analysis revealed various nitrogen impurities with the total nitrogen concentration varying between 40 and $1800 \mathrm{ppm}$. Two paragenetic types of diamonds are distinguished: eclogitic (predominant) and peridotitic ( $12 \%)$.

KIMs (pyrope garnet, chrome spinel, and picroilmenite) in the deposit are well rounded; they are moderately to extensively abraded. The KIMs were found not only in Quaternary sediments but in Cretaceous rocks as well (Kaminsky et al, 1992b; Sobolev et al., 1992). Pyrope compositions indicate their harzburgitic, lherzolitic and eclogitic sources. 


\section{Diamondiferous El Kseibat area}

The El Kseibat area (Fig. 3), like the Reggane area, lies near the border of the Sahara Plate and the West African Craton, of the Ouggarta Range. The first diamond was recovered here during the course of geological mapping (Wilczinski, 1989). Since then nineteen more diamonds (mostly less than $1 \mathrm{~mm}$ in size), about 400 pyrope garnets, one chrome-diopside, and one chrome spinel grain were identified in Quaternary and Cretaceous sediments in this area. All these minerals were found in soil and pit samples; two diamonds were found in early-Quaternary conglomerates (Hamlat, 1999; Acheraiou, 2005).

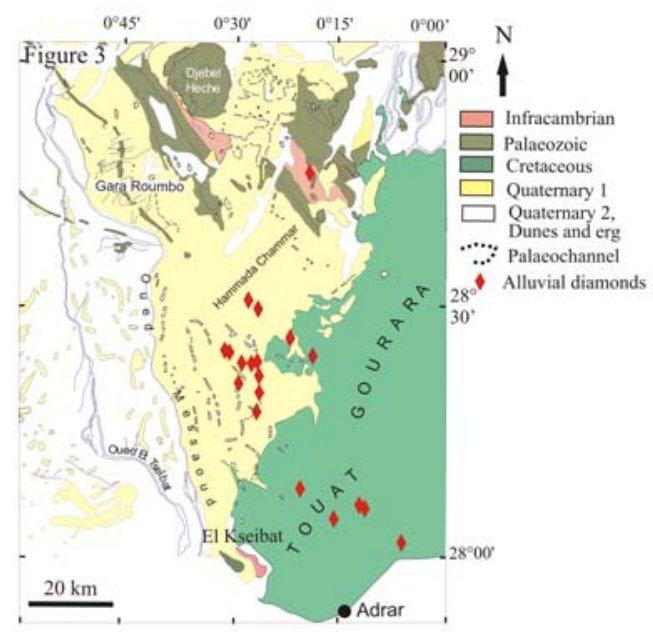

Fig. 3. Geological map of the El Kseibat area.

Diamond crystals are usually octahedral or cubic, colourless, transparent, and some with black inclusions. Pyrope grains are angular or irregular; red, pink or purple in color; strongly abraded and rounded. Analysis of pyrope grains shows the existence of the lherzolitic (G9), harzburgitic (G10) and wehrlitic varieties among them. By the composition and the degree of roundness, the El Kseibat pyropes are similar to the Djebel Aberraz ones; however some of them bear kelyphitic rims.

\section{Prospectivity of the Eglab Shield for diamonds}

The Eglab Shield is in the easternmost part of the Reguibat Rise which is in turn the northern part of the WAC (Fig. 4). It is overlain in the north by the Palaeozoic Tindouf basin, east of the dunes of Erg Chech and the Palaeozoic Reggane basin and in the south by the marine and continental Neoproterozoic Hank series.

The Eglab Shield corresponds to the amalgamation of the Yetti and Eglab Palaeoproterozoic terrains, separated by a mega-shear zone called the 'Yetti-Eglab Junction'. Some 2.7 Ga-old relics of the Archean ocean crust, located near Chegga area, constituted the basement of these Palaeoproterozoic suites and associated volcanic-sedimentary basins (Peucat et al, 2005). Palaeoproterozoic, Neoproterozoic, and Palaeozoic formations are intruded by doleritic and gabbro-doleritic dykes and sills. Analysis of geological, structural, and geophysical features and distribution of KIM show that the most prospective areas for diamond exploration within the Eglab Shield are: (1) the longlived Chenachane shear-zone and (2) the 'Yetti-Eglab Junction'.

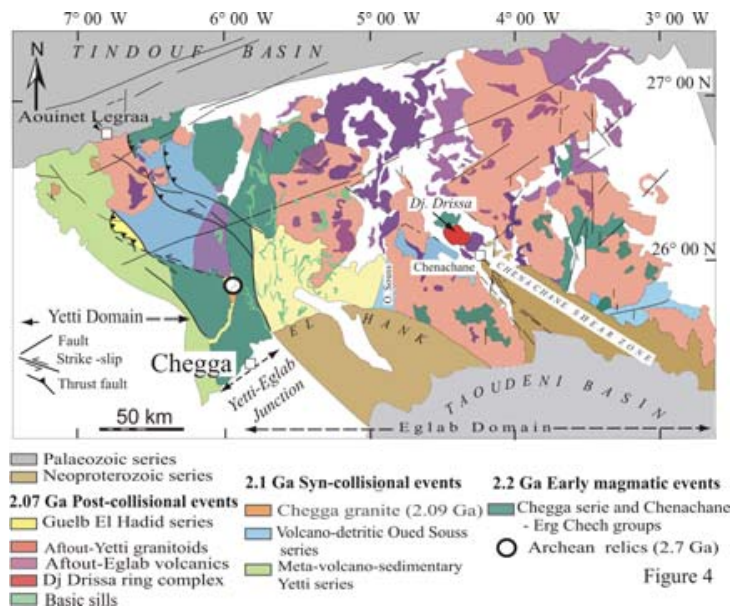

Fig. 4. Geological map of the Eglab Shield.

The long-lived, deep-seated Chenachane shear-zone controls the emplacement of the alkaline/peralkaline Djebel Drissa ring complex. It has been reactivated after the deposition of the Hank series; the latter series are cross-cut by doleritic and gabbro-doleritic sills and dykes. At the intersection of this zone with the NS and NNE-SSW faults, there are magnetic anomalies which may be due to mafic/ultramafic alkaline rocks (possibly including lamproite, kimberlite and/or related rocks) not cropping out (Fig. 5).

The 'Yetti-Eglab Junction' is characteristic of the presence of small dioritic stocks and plutons, gabbroic and mafic/ultramafic alkaline intrusions, and numerous basic dykes. Within this area we localized small (100$250 \mathrm{~m}$ in diameter) circular structures located at the intersection of NNW-SSE and NNE-SSW conjugate faults, ultramafic (komatiitic-picritic) and basic dykes. Some aeromagnetic anomalies with annular forms are superimposed on geological structures; they appear to be controlled by a later extensional or strike-slip postEburnean or pre-Pan-African tectonic (Fig. 5).

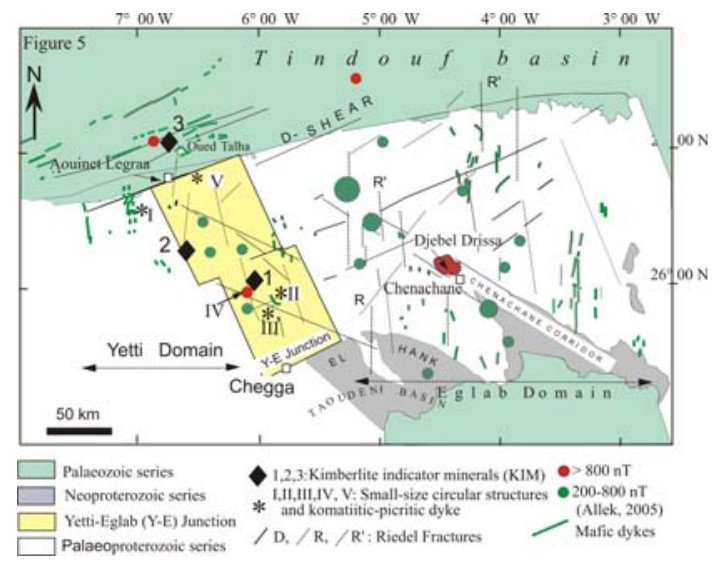

Fig. 5. Kimberlite indicator minerals within the Eglab Shield. 
Prospecting within the Yetti-Eglab Shear Zone and the adjacent part of the Tindouf Basin led to the discovery of forty KIM grains (pyrope, picroilmenite, and chrome-diopside) forming mineral dispersion halos (Labdi and Zénia, 2001). The analyzed garnet grains are located within a low-Ca lherzolitic field and within an eclogitic field (Fig. 6). The latter contains 0.07-0.17 wt.\% of $\mathrm{Na}_{2} \mathrm{O}$ which indicates their possible association with diamonds (Gurney et al, 1993).

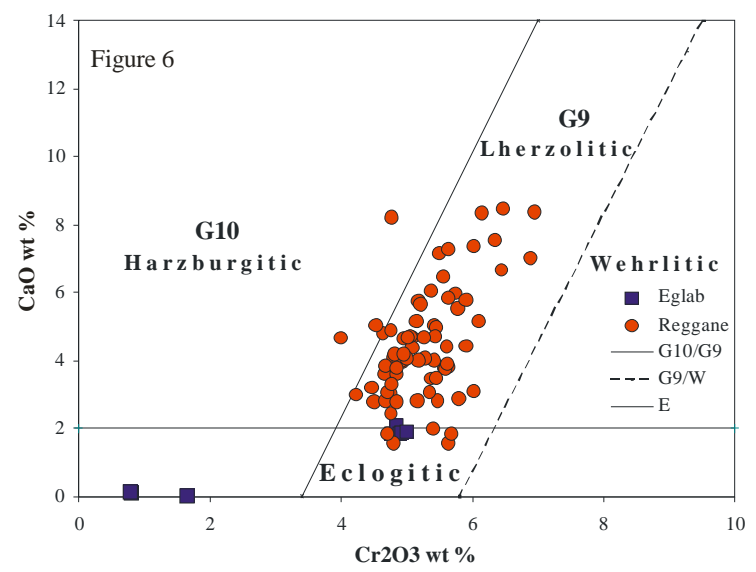

Fig. 6. Ca-Cr diagram for Algerian pyropes.

\section{Conclusions}

The diamondiferous areas known-to-date in Algeria (Reggane and El Kseibat) are located near the border of the Sahara Plate and the West African Craton. Diamonds in these areas along with KIMs (pyrope garnet, chrome spinel and chrome-diopside) form subeconomic concentrations in Quaternary and Cretaceous sediments.

The primary source(s) of diamonds is likely to be kimberlitic (or lamproitic), located within the Eglab Shield which belongs to the WAC.

\section{References}

Allek, K., 2005. Traitement et interprétation des données aéromagnétiques acquises au dessus des blocs de Tindouf et Eglab (Sud Ouest Algérien): Impact sur l'exploration du diamant. Thèse de Magister, USTHB, Alger.

Acheraiou, M., 2004. Rapport sur la prospection du diamant dans la zone de suture entre le Craton Oust Africain et la plateforme. ORGM, Béchar, Algérie.

Gurney,J.J., Helmstaedt, H., Moore, R.O., 1993. A review of the use and application of mantle mineral geochemistry in diamond exploration. Pure and Applied Chemistry, 65, 2423-2442.

Hamlat, R., 1999. Rapport final sur la prospection du diamant dans les secteurs de Bled El Mass (Reggane) et BoudaHamada Chammar (El Kseibat). ORGM, Béchar, Algérie

Kahoui M., Bouzidi O., Razibaouene, A., 1998. La recherche du diamant dans le Saharien Algérien: Synthèse et mise au point. ORGM, Boumerdes, Algérie, 32 p.

Kahoui, M., Mahdjoub, Y., Kaminsky, F.V., 2008. Possible primary sources of diamond in the North African diamondiferous province. In: Ennih, N., Liégeois, J.-P. (Eds.), The boundaries of the West African Craton.
Geological Society, London, Special Publications, 297, 77-109.

Kaminsky, F.V., Verzhak, V.V., Dauev, Yu.M., Buima, T., Boukhalfa, L., Kahoui, M., Salhi, A., Slougi, M., 1992a. The North-African diamondiferous province. Russian Geology and Geophysics, 33(7), 91-95.

Kaminsky, F.V., Kolesnikov, S.K., Petelina, N.A., Hamani, M., Henni, A., Haoufani, M., Verzhak, V. V., Azzie, A., 1992b. Minerals-indicators of diamond in Algerian Sahara. Mineralogicheskii Journal, 14, 15-24 (in Russian).

Labdi, A., Zénia, M.S., 2001. Recherche des sources primaires potentielles de diamant dans le Massif des Eglab. ORGM, Béchar, Algérie.

Peucat, J.-J., Capdevila, R., Drareni, A., Mahdjoub, M., Kahoui, M., 2005. The Eglab Massif in the West African Craton (Algeria), an original segment of the Eburnean orogenic belt: petrology, geochemistry and geochronology. Precambrian Research, 136, 309-352.

Sobolev, N.V., Afanasyev, V.A., Pokhilenko, N.P., Kaminsky, F.V., Tarasyuk, O.N., Henni, A., 1992. Pyropes and diamonds from Algerian Sahara. Doklady Akedemii Nauk SSSR, 325, 367-373 (in Russian).

Wilczynski, M., 1989. Travaux de levé et de recherches systématiques au 1/200 000 sur la feuille NH-VI (El Kseibat). EREM, Béchar, Algérie. 